\title{
貯水池の選択取水に関する研究

\author{
STUDY ON SELECTIVE WITHDRAWAL IN RESERVOIRS
}

\author{
大西外明*.今村建二**. 原口俊蔵*** \\ By Sotoaki ONISHI, Kenji IMAMURA and Shunzo HARAGUCHI
}

\begin{abstract}
A theoretical study on the axisymmetric flow into a point sink in a stratified fluid was conducted by Hino and Onishi ${ }^{1{ }^{1}}{ }^{2)}$, and its theoretical results were verified experimentally by Hino et al. ${ }^{3)}$.4) But these experimental results did not explain any effects of the finite opening on selective withdrawal. Therefore, the data obtained by these experiments are insufficient to adapt in designing the actual intake structures.

The present study was conducted theoretically and experimentally to determine the effects of the dimensions of intake opening on the thickness of the withdrawal layer. Among discussed profiles of density distribution in the reservoir, both non-linear and linear types are included. And velocity distributions in stratified flow toward selective withdrawal finite opening are measured by LDV and useful estimation formula of withdrawal water quality is presented.
\end{abstract}

\section{1. まえがき}

選択取水設備は, 火力原子力発電所の冷却水取水設備 を対象として研究が始められたが, 現在貯水池の水質保 全対策としても幅広く応用されてきている．すなわち， 寒冷地の新設貯水池には例外なく選択取水設備が備えら れるほか他地域にも同様の傾向がみられ，また既設の従 来方式取水設備を選択取水設備に改造するケースも珍し いことではない.このような状況下にあって, 選択取水 設備の合理的設計法の確立が必要となってきている.

選択取水の研究は, 日野・大西 ${ }^{1}$ によって提示された 一定密度勾配域における軸対称流れの研究によって, 大 きな進展が得られた. その研究において, 日野・大西は, まずポイントシンクへの流れの理論解を示し, ついで, 有限寸法取水口への理論解を示した2).

それらの, 日野・大西の理論解の妥当性の実験的検証 は日野ら ${ }^{3)} よ り$, 取水半径の小さいポイントシンクに

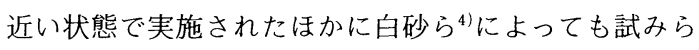
れたが, 取水口寸法と流動層厚さとの関係を把握するに はいたっておらず, 実際の設備の設計に適用するには不

* 正会員 工博 東京理科大学教授 理工学部土木工学科

** 正会員 三菱重工(株高砂研究所 流体研究室主務 ( ₹ 676 高砂市荒井町新浜 2-1-1)

*** 三菱重工(株)横浜製作所 水門鉄管設計課主任
十分な点があった。

また，貯水池の選択取水を対象とする場合，そこの水 温分布は，本文の Fig. 7 に示すごとく，水深方向に直線 近似を適用するには無理な場合が多々ある.

次に，選択取水時の取水水質を算定するには水温分布 と流動層内流速分布との関係の把握が不可欠である．流 動層内流速分布に関しては, Harleman ${ }^{51}$ の提唱に基ゔ く正規分布関数近似が広く用いられてきているが，それ は表層取水時の流れに適用するには無理があった。

これら問題点に関し, 本研究においては, 门) 日野・ $大^{\text {大西 }^{2}}$ の理論的研究を応用して, 解析的に, 取水口寸法 が流動層厚さに及ぼす影響を求め，それを実験的に検証 した． ii）上記ｉ）の研究結果をもとにして貯水池の表 層取水を対象とし, 密度勾配が変化する場合の流動層厚 さの推定法を実験的に求めた. iii ）流動層内の流速分布 を LDV で計測して, 取水水質算定に供し得るようにま とめた.

これらの研究結果は, 現地実測結果との照合に対して も実用性が確認された。

\section{2. 有限寸法取水口を有する軸対称流密度成層 流の理論(1),}

流体は対象としている水域の上面から下面まで直線的 
に密度 $\rho$ が増大しており, 非粘性かつ混合による拡散 がないとする.Fig.1のような座標系および記号を採用 すれば，無次元化された流関数 $\psi$ に関して表わした流 体の運動基礎方程式は，日野・大西によって導かれたよ うに,

$$
\frac{1}{\xi^{2}}\left(\frac{\partial^{2} \psi}{\partial \xi^{2}}+\frac{\partial^{2} \psi}{\partial \eta^{2}}-\frac{1}{\xi} \cdot \frac{\partial \psi}{\partial \xi}\right)+G^{-2} \psi=-G^{-2} \eta
$$

である.ここに，Gは日野・大西の選択取水数であり， 次式により定義される.

$$
G=\frac{Q}{2 \pi \sqrt{g \beta} d^{3}} \text {. }
$$

ここに, $Q$ は取水量, $\beta$ は密度成層度の強さを表わすパ ラメーターで水域下面の密度を $\rho_{0}$, 上面の密度を $\rho_{1}$ と すると下式で定義される.

$$
\beta=\left(\rho_{0}-\rho_{1}\right) / \rho_{0} d
$$

取水口は半径 $r$ の取水塔の $\eta=a$ と $\eta=b$ の間にあ り,この $\eta=a, b$ の間で流関数 $\psi$ が 0 から 1 まで変化 する.これを下式で表わす.

$$
\psi(r, \eta)=f(\eta) \quad(\xi=r, a \leq \eta \leq b)
$$

他の境界条件は次のごとくなる.

$$
\begin{array}{ll}
\psi(\xi, \eta)=-1 & (0 \leq \xi<\infty, \eta=1) \\
\psi(\xi, \eta)=-\eta & (\xi \rightarrow \infty, 0 \leq \eta \leq 1) \\
\psi(\xi, \eta)=0 & (0 \leq \xi \leq \infty, \eta=0) \\
\psi(\xi, \eta)=0 & (\xi=r, 0 \leq \eta<a) \\
\psi(\xi, \eta)=-1 & (\xi=r, b \leq \eta \leq 1)
\end{array}
$$

式（1）の摂動法による第 3 近似までの解が，日野・ 大西により下記のごとく得られた2)

$\psi(\xi, \eta ; a, b, r)$

$$
\begin{aligned}
= & -\eta+\sum_{n=1}^{\infty} B_{n}(a, b, r) \sin n \pi \eta\left[\xi K_{1}+\frac{\mu_{1}}{6 n \pi} \xi^{4} K_{2}\right. \\
& +\frac{\mu_{2}}{6 n \pi} \cdot \xi^{7}\left\{\frac { \xi } { 1 2 } \left(-I_{1} K_{2} K_{3}\right.\right. \\
& \left.+I_{1} K_{3} K_{4}+I_{3} K_{1} K_{2}+I_{4} K_{1} K_{3}\right) \\
& \left.\left.+\frac{2}{5 n \pi}\left(\frac{K_{2}}{n \pi \xi}-I_{1} K_{3}^{2}+I_{3} K_{1} K_{3}\right)\right\}+\cdots\right]
\end{aligned}
$$

ここに， $I_{k}, K_{k}$ 等は $n \pi \xi$ を独立変数とする第一種およ び第二種の変形 Bessel 関数であり, 係数 $\mu_{1}, \mu_{2}$ は $G$ の大きさにより次のような值をとる.

$$
\begin{aligned}
& {[G>1] \quad \mu_{1}=G^{-2}, \mu_{2}=G^{-4} .} \\
& {[G<1] \quad \mu_{1}=G^{-2}, \mu_{2}=1 \cdots}
\end{aligned}
$$

また係数 $B_{n}(a, b, r)$ は下記のごとくなる.

$$
B_{n}=2\left[\int_{a}^{b} f(\eta) \cdot \sin n \pi \eta \cdot d \eta-\frac{\cos n \pi b}{n \pi}\right] /\left[r K_{1}(n \pi r)\right]
$$

ここに $K_{1}(n \pi \xi)$ は $n \pi \xi$ を独立変数とする第二種の変形 Bessel 関数である.

関数 $f(\eta)$ については，ある程度の自由性を与えると

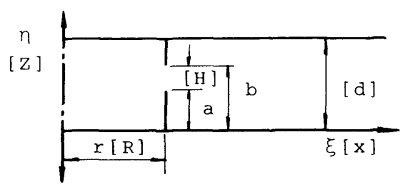

Fig. 1 Cylindrical coordinates and Symbols (Symbols in braces are dimensional, others are non-dimensional normalized by thickness of withdrawal layer [d])

ともに，上記式（8）を実際計算しやすいように次のご とくおく.

$f(\eta)$ を $f(a)=0, f(b)=-1$ の間の直線, 放物線お よび三次曲線の和で表わす。

すなわち，

$f(\eta)=f_{1}(\eta)+p_{2} f_{2}(\eta)+p_{3} f_{3}(\eta)$

ここに

$$
\begin{aligned}
& f_{1}(\eta)=-(\eta-a) /(b-a) \cdots \\
& f_{2}(\eta)=(\eta-a)(\eta-b) \cdots \cdots \cdots \\
& f_{3}(\eta)=(\eta-a)(\eta-b)(\eta-c) \\
& c=(b-a) / 2
\end{aligned}
$$

上記の $f(\eta)$ を用いれば

$\int_{a}^{b} f(\eta) \cdot \sin n \pi \eta \cdot d \eta$

$$
\begin{aligned}
& =\frac{1}{b-a}\left[p_{3} I_{3}+\left\{p_{2}-p_{3}(a+b+c)\right\} I_{2}\right. \\
& +\left\{(a b+b c+c a) p_{3}-(a+b) p_{2}-1\right\} I_{1} \\
& \left.+\left\{a+p_{2} a b-p_{3} a b c\right\} I_{0}\right] \text {. }
\end{aligned}
$$

ここに

$$
\begin{aligned}
& I_{3}=(n \pi)^{-4}\left[(n \pi b)^{2}(3 \sin n \pi b-n \pi b \cdot \cos n \pi b)\right. \\
& -(n \pi a)^{2}(3 \sin n \pi a-n \pi a \cdot \cos n \pi a) \\
& -6(\sin n \pi b-n \pi b \cdot \cos n \pi b) \\
& +6(\sin n \pi a-n \pi a \cdot \cos n \pi a)] \\
& I_{2}=(n \pi)^{-3}[n \pi b(2 \sin n \pi b-n \pi b \cdot \cos n \pi b) \\
& -n \pi a(2 \sin n \pi a-n \pi a \cdot \cos n \pi a) \\
& +2(\cos n \pi b-\cos n \pi a)] \\
& I_{1}=(n \pi)^{-2}[\sin n \pi b-\sin n \pi a-n \pi b \cdot \cos n \pi b \\
& +n \pi a \cos n \pi a]
\end{aligned}
$$

上述のごとくして水域内の任意の点における流関数 $\psi$ を計算することにより，密度勾配を有する水域の流動状 況を解析することができる.

その解析解は，Gが大きい場合には非粘性流動状況 を示し， $G$ が小さい場合には非粘性流動状況とは異な り，渦を伴う流れを示す，日野・大西は，そのような渦 の発生条件に関する考察を通して, 選択取水が可能とな る条件を流動状況解析から求める考え方を示した ${ }^{11}$. そ の考え方の本研究への具体的適用について次節に詳述す る. 


\section{3. 選択取水数 $\boldsymbol{G}_{c r}$ の解析解 ${ }^{6)}$}

選択取水状態が, 取水量 $Q$, 密度成層度パラメ一 ター $\beta$ また流動層厚さ $d_{s}$ のもとに達成できるとき，そ の条件に対する選択取水数を $G_{c r}\left(=Q /\left\{2 \pi \sqrt{g \beta} d_{s}^{3}\right\}\right.$ と記 号づける. 前述の流関数計算による流動状況解析をとお して， $G_{c r}$ の解析解を以下に求める.

\section{（1） 表層取水の $G_{c r}$}

表層取水時の流れ解析結果の例を Fig. 2 に示す．同図 の例は $G$ が小さく, 渦が発生している場合の流動状況 である．この渦領域の大きさは， $G$ の值に関連するこ とは, point sink への流れの場合と同様である ${ }^{11}$.

この計算上の渦領域は, 実現象ではよどみ域になるこ と，またそのよどみ域の発達により，水域は無限遠点ま でよどみ域と流動層とに分けられることが知られてい る. 本解析では, Fig. 2 に示すように $1 \geq \eta \geq-\infty$ の水 域のなかで $1 \geqq \eta \geqq 0$ の水域（すなわち, 流れの解析水域) がちょうど流動層になる条件を求める.この点に関して は日野らは point sink への流れの研究において, “解析 水域内の $\xi \geqq 0.5$ の領域に渦が残らない場合が, 解析水 域を無限遠点まで流動層とする条件に近い”考察して, $G_{c r}$ の解析解を求め，それを実験により検証している.

今回の研究においても，それを参考として，取水半径 が $r$ の場合には， $\xi \geqq r+0.5$ の領域に渦領域が残らな いという条件から $G_{c r}$ の解析解を求めた。 なお, その解 析解を求めるうえで,式( 9 )の $p_{2}$ および $p_{3}$ は 0 とした.

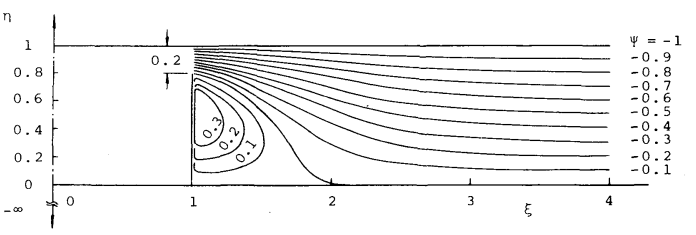

Fig. 2 Example of Flow Pattern Analytically Obtained for Upper Layer Withdrawal $(G=0.3)$.

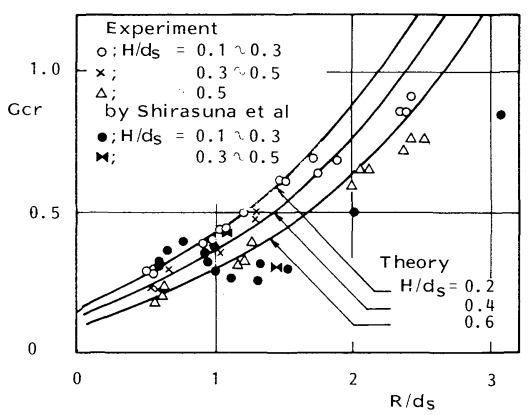

(a) Upper Layer Withdrawal
すなわち，呑口部の流速值は，高さ方向に一定值とした

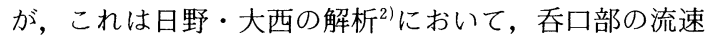
分布は渦領域の大きさに及ぼす影響は小さいことが明ら かにされていることを参照したものである．取水半径お よび取水開口高さを種々変えた場合の $G_{c r}$ の解析解を Fig. 3 (a) に示す. 同図には後述する実験デー夕もあわ せて示してある。

\section{（2）中層取水の $\boldsymbol{G}_{c r}$}

中層取水の $G_{c r}$ の解析値も表層取水之同様の考元から 求まるが, 表層取水と異なるのは渦なし領域を $\xi \geqq r+$ 0.25 とするところにある．その説明を以下に記す。

Fig. 4 に中層取水の流れの説明図を示すが，同図にて 明らかなごとく, 流れは $\eta=0.5$ を対称面とする上下対 称流とみなすことができる. また，その対称流は， $\eta=$ 0.5 を表面とし流動層厚さが $d_{s} / 2$ の表層取水と, $\eta=$ 0.5 を底面とする下層取水とみなすことができる. 下層 取水の特性は表層取水之同一であるから，中層取水特性 は表層取水特性からも説明されなければならない.

さて, 表層取水特性解析における $\xi=r+0.5$ の位置 とは, 有次元数に置き換えると娵水半径 (有次元值) + $0.5 \times$ 表層流動層厚さけの位置であることを考えて，それ に相当する位置を中層取水の上下対称流について求める と 仅水半径 (有次元值) $+0.5 \times 0.5 \times$ 中層取水流動層厚 さり位置となる.これを中層取水流動層厚さで無次元 化すると $\xi=r+0.25$ となり, 前述の中層取水における 渦なし領域の限界点となる。

上述の考えと, 流れ関数計算結果から得た中層取水の $G_{c r}$ の解析解を Fig. 3 (b) に示す. 同図には, 表層取 水の場合之同様に, 後述する実験データが併記してある.

なお，日野・大西の point sink への流れの研究にお いて, 中層取水の $G_{c r}$ は表層取水の $G_{c r}$ の $1 / 4$ となるこ とが示されている. 今回の, 有限寸法取水口を対象とし た研究においても同样な関連性が保持されているが，そ れにも取水口寸法が影響する。すすなわち，Fig. 4 の記号

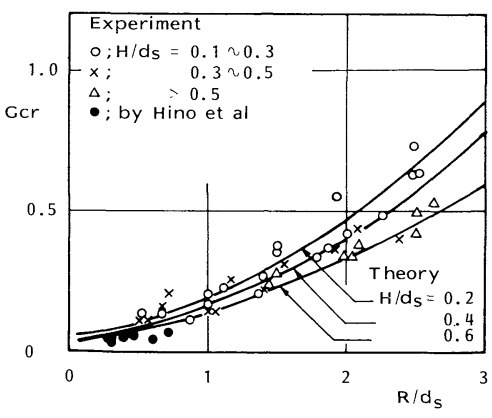

(b) Middle Layer Withdrawal

Fig. 3 Critical Value of Modified Densimetric Froude Number : $G_{c r}\left(d_{s}:\right.$ thickness of withdrawal layer, $H$ and $R$ : height and radius of intake). 


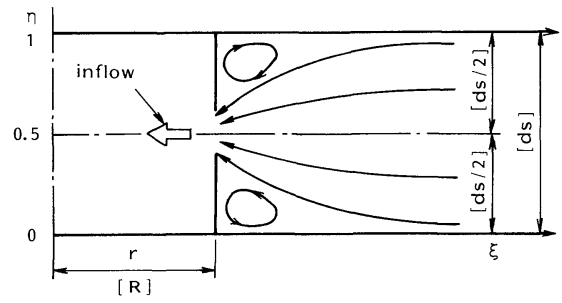

Fig. 4 Schema of middle Layer Withdrawal (Values in braces are dimensional).

を用いて説明すると，表層取水に関しては

$$
G_{c r}=\frac{Q / 2}{2 \pi \sqrt{g \beta}\left(d_{s} / 2\right)^{3}}=4 \frac{Q}{2 \pi \sqrt{g \beta} d_{s}^{3}}
$$

であり，そのときの無次元取水半径は

$$
r=R /\left(d_{s} / 2\right)=2 R / d_{s}
$$

である。一方中層取水に関しては

$$
G_{c r}=\frac{Q}{2 \pi \sqrt{g \beta} d_{s}^{3}}, r=R / d_{s}
$$

である.したがって, 表層取水の $R / d_{s}=2$ の場合の $G_{c r}$ の $1 / 4$ が中層取水の $R / d_{s}=1$ の $G_{c r}$ にほぼ合致し なくてはならないが，Fig.3（a）および（b）にその関 係をみることができる。もとより上記の関係は，表層取 水の $R / d_{s}=1$ の点と中層取水の $R / d_{s}=0.5$ の点等 $R /$ $d_{s}$ が 2 対 1 の比をとる任意の点についてもいえる.

\section{4. 実験による検証 ${ }^{6)}$}

\section{(1) 実験装置}

Fig. 5 に実験装置の説明を示す. 密度勾配は温度勾配 により形成した，すなわち，同図において，温水タンク および冷水タンクからポンプにより温水および冷水を吸 引し, 温冷水混合部で所定の水温の温水にする. それを 温水案内板を経て試験水槽に導く.

温水案内板は 10 層からなり，温度を調節された温水 を下層から順次ゆるやかに試験水槽内に満たし，水槽内 の温水の層を重ねていくことにより，多様の水温分布を 形成することができた.
試験水槽は軸対称流試験のための矩形水槽と, 水路幅 $200 \mathrm{~mm}$ の二次元流試験部からなる.

軸対称流試験においては, 半円取水口を水槽壁に装着 して取水し, 流動層厚さの測定は, 色素トレーサーの移 動領域を読み取る方式をとった. 流動層厚さ測定位置は, 取水口中心から 500 1 $000 \mathrm{~mm}$ かつ, 側部の観察空壁 から 300 500 mm 離れた位置とし, 各試験条件 (取水 半径や流動層厚さを変化させた諸条件）に対して，ほほ 一定流動層厚さが観察される領域を選んだ.

二次元流試験部には, レーザー流速計により, 流動層 内の流速分布測定が可能な装置を設置した.

二次元流試験の際は表面から $20 \mathrm{~mm}$ の深さを有する 二次元取水口から取水した。

取水時に水槽内の水位が低下するのを防止するため に，水槽底部から冷水を補給した。こうすることにより 当初に水槽内に形成した温度分布を実験中比較的長く保 存することが可能であった。

\section{（2） 選択取水数 $\boldsymbol{G}_{\boldsymbol{c} r}$ の実験值}

実験で得られた $G_{c r}$ を，Fig.3 (a)，(b) に解析解之 あわせて示す．実験においては， $G_{c r}$ の解析解が示した 特性，すなわち $G_{c r}$ は $R / d_{s}$ および $H / d_{s}$ の值によっ て変化するということを, 実機設備設計上の実用的範囲 を網羅して検証することを目的とし，ほぼそれを達成す ることができた。その実験条件の概要については Table 1 を参照されたい.Fig. 3 (a)，（b) に示した実験值と 解析解とは， $G_{c r} \doteqdot 0.7$ 程度までよく合致している.

なお Fig.3 (a) において, $R / d_{s}$ が大きい領域では 解析解之実験值の差が増大し, $G_{c r}$ の実験值は $R / d_{s}$ 之 ともに直線的に増加する傾向が認められる.この傾向は, $R / d_{s}$ の増大につれ流れが二次元流の性状を有してくる ことを示している.

\section{（3）従来の実験研究結果との比較}

$G_{c r}$ を実験的に求めた研究として, 日野・古沢 ${ }^{31}$ およ び白砂・安芸 ${ }^{4}$ の研究がよく知られている. それらの研 究と今回の研究を照合してみる.

a) 日野・古沢の実験との比較

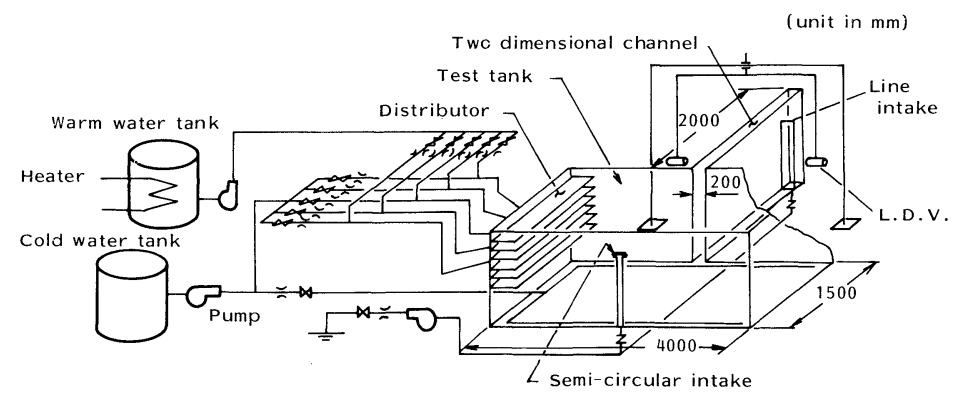

Fig. 5 Schematic Drawing of Experimental Apparatus (unit in $\mathrm{mm}$ ). 


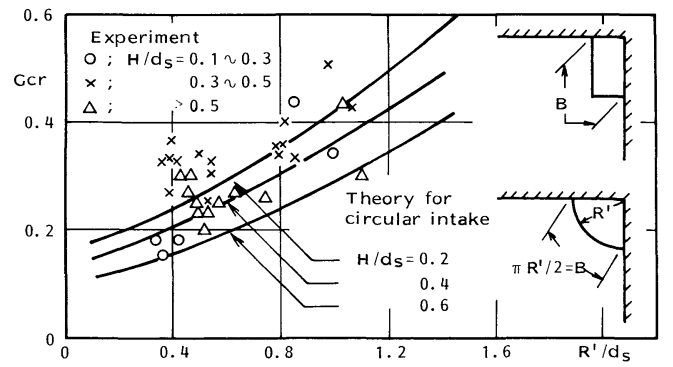

Fig. $6 G_{c r}$ of Rectangular Intake for Upper Layer Withdrawal (Experimental data were presented by Shirasuna et al. $\left.{ }^{4)}\right)$.

日野・古沢は point sink への流れに対する中層取水 の $G_{c r}$ の検証を主目的として実験を行った. そのデータ をFig. 3 (b) に本研究の解析解および実験データとあ わせて示す. 本研究の解析解および実験データは, 日野 らのそれに比し大きめであるが, 実験デー夕同士の差異 は実験手法の差異にも起因していると考える.すなわち， 日野らの実験における流動層厚さの決定法は，取水はじ めに互層に作った状態と, 十分に選択取水が進んで水深 の低下が大きくなった状態とを比べて，層厚に変化のな かった層をよどみ層としている.しかしながら日野らの 実験值と本研究のそれとの差異は，密度流では許容でき る範囲であり, 本研究と日野・古沢の実験は合致してい るとみてよい.

b) 白砂・安芸の実験結果 ${ }^{4)}$ との比較

白砂・安芸は表層取水の $G_{c r}$ に関し，1/3 円周取水口 と矩形取水口に関して実験し, その平均值として $G_{c r}=$ 0.324 を提唱したことで知られている.ここに白砂らの 実験法は本研究のそれと同様である.その実験データ中, 1/3 円周取水口に関する $G_{c r}$ を Fig. 3（a）に他デー夕と あわせて示す.同図より,本研究の解析解および実験デー 夕は, 白砂らのそれとはほぼ同值であること, また $R / d_{s}$ の増大とともに $G_{c r}$ が大きな值をとる傾向についても, 白砂らのデータの $R / d_{s} \fallingdotseq 2$ および 3 近辺の点のデータ に同傾向をみることができる.

矩形取水口の場合の $G_{c r}$ は, 本研究の対象である円形 取水口の $G_{c r}$ とは多少異なるであろうが，白砂らが $1 / 3$ 円周取水口に関する実験結果と矩形取水口に関する結果 を合わせた平均值として， $G_{c r}=0.324$ を提唱したこと

Table 1 Summary of Experimental Conditions.

\begin{tabular}{|ll|l|}
\hline Intake Radius & $; \mathrm{R}(\mathrm{cm})$ & $7.5,14,25$ \\
Intake Opening Height & $; \mathrm{H}(\mathrm{cm})$ & $2 \sim 7.5$ \\
Intake Flow Rate & $; \mathrm{Q}\left(\mathrm{cm}^{3 / \mathrm{s}}\right)$ & $300 \sim 1400$ \\
Density Gradient & $; \mathrm{B}(1 / \mathrm{cm})$ & $1.3 \sim 5.6 \times 10^{-4}$ \\
$\begin{array}{l}\text { Thickness of Withdrawal } \\
\text { Layer }\end{array}$ & $7 \sim 15$ \\
\hline
\end{tabular}

に推察されるごとく, 双方のデー夕はほぼ類似のもので あると考えられる.そこで矩形取水口の $G_{c r}$ にも，本研 究で対象としている取水口寸法の影響が含まれているか 否かについて，以下に近似的取り扱いであるが検討を加 えてみる.

矩形取水口幅 $B$ (Fig. 6 の説明図参照) のかわりに, それと同じ円周長さを有する取水半径 $R^{\prime}=B /(\pi / 2)$ (Fig. 6 の説明図参照) を考え， $R^{\prime} / d_{s}$ に対して矩形取 水口に関する $G_{c r}$ の実験值と円形取水口に関する $G_{c r}$ の 解析解をプロットすると, Fig. 6 に示す結果が得られた.

Fig. 6 の結果から，矩形取水口の $G_{c r}$ の実験值は $R^{\prime}$ の值によって変化しており, したがって, 取水口幅 $B$ の影響を含んでいると考えられる. そして, その取水口 寸法の影響は, 今回の研究の対象である円形取水口の場 合と非常に類似していると考える.これらの比較から, 白砂・安芸の実験は, 大部分が $R / d_{s}=0.6 \sim 1.5$ ある いは $R^{\prime} / d_{s}=0.4 \sim 1.1$ の範囲で行われていることをみ ることができる.

そして, 彼らの実験の平均值である $G_{c r}=0.324$ は, 上述の取水口寸法に対する值として説明づけられる.

\section{5. 密度勾配が変化する水域への応用性の拡張}

Fig. 7 に, 貯水池の表層近辺の水温分布計測結果の例 を示す。近年選択取水設備が，貯水池の表層取水に多用 されてきており,また, その機能の良否は農業および環 境に影響を与える度合が大きいことを考えると, Fig. 7 のような水温分布水域の選択取水特性の研究が望まれて いた. このように密度変化勾配が変化する水域に関して は解析解を求める手法はまだ確立されてなく，またそれ はかなりの困難を伴うと考えられる.そこで本研究では 前述の密度勾配が一定の場合の解析解およびその実験検 証值をべースにし, 貯水池の水温分布を対象亡する場合 には, 実験的補正值を適用することにより, 実機設計へ の応用性の拡張を図った。

\section{（1）代表密度勾配の提案}

前述の式（２）は, 密度勾配が一定の条件のもとの選

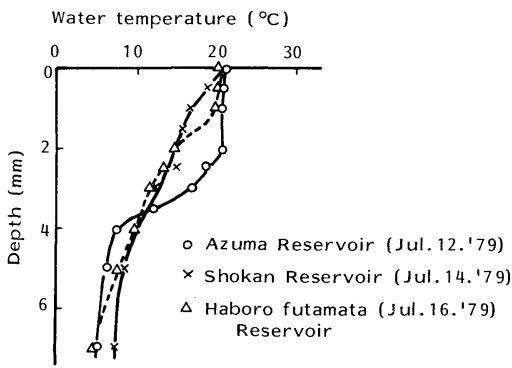

Fig. 7 Examples of Water Temperature Distribution in Reservoir. 


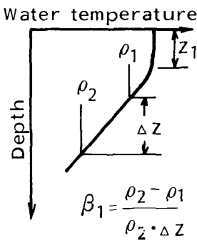

(a) Type $\cdot A$

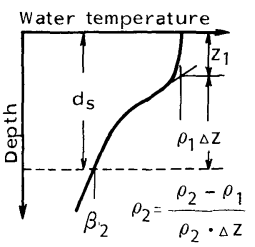

(b) Type-B
Fig. 8 Respective Density Gradient $\left(z_{1}\right.$ : Depth of almost same water temperature).

択取水状態を規定する内部フルード数であるが, 密度勾 配が変化する場合も，密度勾配パラメーターを適切に選 定すれば(ここではそれを代表密度勾配と名づける)， その密度変化状態に関する選択取水状態を規定する内部 フールド数ひいては選択取水数が, 式 (2) と同じ形で 表現できると考えられる．ただし，密度分布形状が変化 することに伴う補正を，式（2）に付加することが必要 となる。

本論文では，密度勾配が変化する場合の，選択取水流 動層近辺の代表密度勾配の定め方として, Fig. 8 に示す 方法を考えた。この方法は次の考え方に立っている．ま ず，現地の水温分布パターンを，次の考え方でとらえる. i ) 表層近辺に，ほぼ一定水温域がある. ii ）その水域 の下方に温度勾配域がある。iii）その温度勾配域は, Fig. 8 (a) のように，1個の直線で近似し得る場合と, Fig. 8 (b) のように, 2 個の直線近似を要する場合とが ある. 次に前述の水温分布パターンを, 次のように模型 化する．1）表層近辺の，ほぼ一定水温域水深 $z_{1}$ として, 前述 ii ）の水温勾配の接線之，一定水温近似線の交点の 水深をとる. ii ) Fig. 8 (a) のように， $z_{1}$ を除く水深 の温度勾配が，1個の直線で近似し得る場合は，之の直 線の勾配を代表密度勾配として採用する。iii ）Fig. 8 (b) のように, 2 個の直線による近似を必要とする場合は, まず流動層厚さ $d_{s}$ を仮定し,$\Delta z=d_{s}-z_{1}$ の水深間の 平均密度勾配を代表密度勾配として採用する。そそして試 験水槽内に種々の水温分布をもつ密度場をつくり，選択 取水流動層厚さ $d_{s}$ を計測し，得られた $d_{s}$ 之代表密度 勾配を式 (2) に代入して, 密度勾配が変化する場合の
選択取水数を求めてみた。さらに，Fig. 8 に示す代表密 度勾配および取水量に対して測定された流動層厚さは, その代表密度勾配で全水深にわたり密度が変化するもの 亡仮定して式（2）より求めた流動層厚さに比し，に゙の ように変化するかを比較してみた。

\section{(2) 実験条件}

Fig. 9 に温度勾配が変化する場合の選択取水数を求め るために行った実験における水温分布の例を示す.

この図に示した水温分布の形状を定めるに際しては, 実際の貯水池における水温分布の typical なものを力 バーし得るように, 表層近辺のほぼ一定水温域の厚さを 変えるとともに，その下方の水温勾配の変化部について も，前の Fig. 8 (a) に示されるような 1 個の直線で表 現される分布，および Fig. 8 (b) のように 2 個の直線 で近似化し得るような分布をもたせるように配慮した。

\section{（3）実験結果}

いま，Fig. 9 に例示した試験条件に対する代表密度勾 配, 取水量および流動層厚さから算出した選択取水数を $G_{c r}^{\prime}$ 之記号づける.

$$
\begin{aligned}
& \text { すなわち, } \\
& G_{c r}^{\prime}=Q /\left\{2 \pi \sqrt{g \beta_{1}} d_{s}^{3}\right\}
\end{aligned}
$$

あるいは，

$$
G_{c r}^{\prime}=Q /\left\{2 \pi \sqrt{g \beta_{2}} d_{s}^{3}\right\}
$$

他方それらの代表密度勾配で全水深にわたって密度が変 化すると仮定した場合の選択取水数が前掲 Fig. 3 (a) から求まる.

この $G_{c r}^{\prime}$ と $G_{c r}$ との比を示したのが Fig. 10 である. 計測結果は多少のばらつきを示しているが，平均的な傾 向をみることができる，なお，このばらつきには， $G_{c r}$ および $G_{c r}^{\prime}$ の計算にあたっての流動層厚さの $d_{s}$ の 3 乗 の項が大きく影響をしていると考えられる.

すなわち, 流動層厚さ計測值のばらつきが約 3 倍に拡 大されて，選択取水数のばらつきとして示されているわ けであるが，この観点にたてば，Fig.10に現われたば らつきは，この種の密度流の実験ではやむを得ない範囲 のものと考える.

Fig. 10 をみると，表層にほぼ一定水温域がある場合， 代表密度勾配を用いた選択取水数すなわち $G_{c r}^{\prime}$ は $G_{c r}$
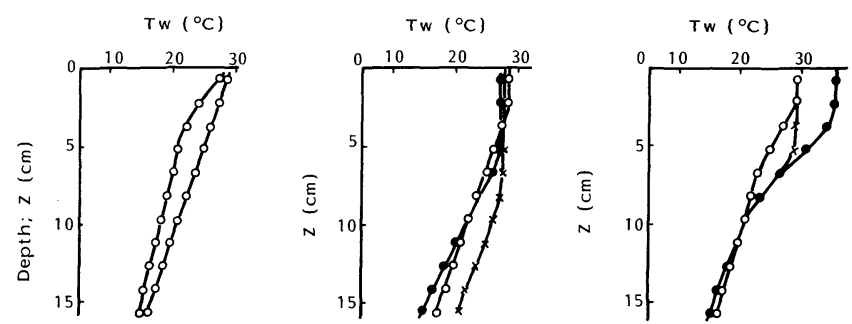

Fig. 9 Examples of Water Temperature Distribution in Model Test. 


\begin{tabular}{|c|c|c|c|}
\hline & $\begin{array}{l}\text { Respective den- } \\
\text { sity gradient }\end{array}$ & $\mathrm{R} / \mathrm{ds}$ & $\mathrm{H} / \mathrm{ds}$ \\
\hline $\mathbf{0}$ & Type - B & & $\approx 0.4$ \\
\hline & $\mathrm{A}$ & $\approx 1.2$ & $\approx 0.2$ \\
$\Delta$ & $\mathrm{B}$ & & \\
\cline { 2 - 4 } & $\mathrm{A}$ & & $\approx 0.4$ \\
$\times$ & $\mathrm{B}$ & $\approx 0.65$ & $\approx 0.4$ \\
\hline
\end{tabular}

$\mathbf{R}$

$\mathbf{H}$ :

ds :

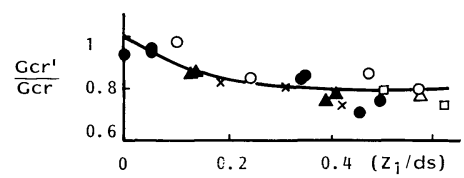

Fig. 10 Experimental Results on $\boldsymbol{G}_{c r}^{\prime}$ in relation to $\boldsymbol{z}_{1}$.

に比し小さな值をとる.これは，表層にほぼ一定の水温 域がある場合，それを含む流動域の密度勾配は実質的に 小さいものになっているわけであるから，流動層厚さを 大きくする効果を生み，ひいては選択取水数を小さくす る効果を生むためと考えられる.

\section{6. 流動層内流速分布の測定}

選択取水流動層内の流速分布の把握は, 取水水質の算 定に不可欠であるが，通常，流速值が非常に小さく，計 測が困難であることから，従来の研究のなかには十分な 資料を見出すことができない.

本研究では，LDVを用いることにより，精度高い計 測を行うことができた.なお，計測は二次元流に関して， 前方散乱形の LDV を用いて実施した。

\section{（1）流速分布測定結果}

Fig. 11 に表層取水時の流速分布測定結果を示す. 同 図には，後に述べる実験式による流速分布もあわせて示 してある.また同図（a) において， $h_{s p}$ として示して あるのは，二次元流の流動層厚さに関するYih の理論

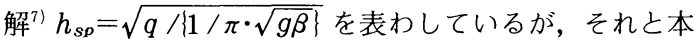

実験結果とはほぼ一致している.

Fig. 11 に示す計测結果に関する特徵的事項として, 次の点を挙げることができる.

）表層取水流動層内流速分布は，表層近辺で流速 が大きく, 水深の増大とともに流速はしだいに減少する.

ii ）上記の流速分布は，水温分布によって変化する. すなわち，同図（b）および（c）のごとく，表層近辺 にほぼ一定水温域がある場合，その水域内に流速のほぼ 一定の領域が生ずる。

上述の事項は，従来の研究においても現象的には報告 されていたが, 本研究では，これを数值的に把握したこ とに加え, 水温分布条件の変化に対する流速分布の変化 を系統的に知ることができた点に意義がある。

\section{（2）流速分布の実験式表示の試み}

上に示した流速分布を，数式で近似表現することを試 みる．この目的とするところは，実機の設計において， 取水温度の算定に便を図ることにある.

いま, $z$ を水深, $d_{s}$ を流動層厚さ, 水温分布を $T(z)$, 流動層内流速分布を $v(z)$, その最大值を $V_{\max }$ とすると 取水温度 $T_{w}$ は次式で与えられる.

$$
T_{w}=\frac{\int_{0}^{d_{s}} T \cdot v d z}{\int_{0}^{d_{s}} v \cdot d z}=\frac{\int_{0}^{d_{s}} T \cdot v / V_{\max } \cdot d z}{\int_{0}^{d_{s}} v / V_{\max } \cdot d z}
$$

上記の計算において, 水温分布 $T(z)$ は設計条件之 して与えられるので, $v(z) / V_{\max }$ が，水温分布の影響を 考慮に入れた状態で実験式化されていれば，計算に至便 となる。

実験式化の考え方を Fig. 12 に示す．すなわち，本論 文では下記の 3 点の考えに基づいて $v(z) / V_{\max }$ を実験 式化することとした.

i）最大流速域は水表面にある。また，表層近辺に ほぼ一定水温域がある場合は，その水域の一部にも，最 大流速が生ずる.

ii）流動層の下方に向かうに従って, 流速が減少し

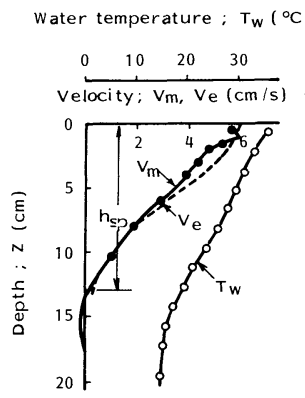

(a)

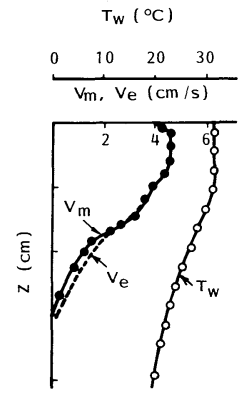

(b)

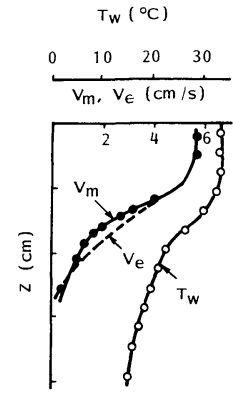

(c)

Fig. 11 Velocity Distributions in Upper Layer Withdrawal Layer ( $V_{m}$ : measured velocity, $V_{e}$ : estimated velocity by Eq. (14)). 


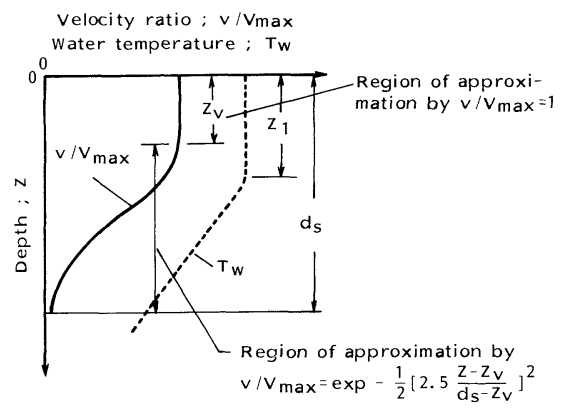

Fig. 12 Derivation of experimental formula for velocity distribution in withdrawal layer.

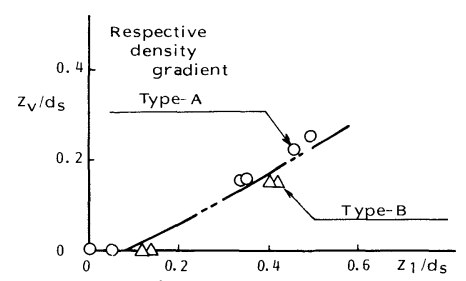

Fig. 13 Experimental Results on $z_{v}$ in relation to $z_{1}$.

ていく状況を正規分布関数の一部で近似する.

iii） Fig. 12 における $z_{v}$ すなわち, 流速一定近似水 深については, 水温分布と流速分布との関係の計測結果 をもとに決定する.すなわち，Fig. 11 に例示するごと く種々の水温分布に対する流速分布を計測して, Fig. 12 の $z_{v}$ に近似できる水深を読み取って整理すると, Fig. 13 に示す結果が得られた.この Fig. 13 に示す実験 値を用いる.

上記を具体的に数式化すると下記のごとくなる.

$$
\frac{v}{V_{\max }}= \begin{cases}1 & ; z<z_{v} \\ \exp -\frac{1}{2}\left[2.5 \frac{z-z_{v}}{d_{s}-z_{v}}\right]^{2} & ; z_{v} \leq z \leq d_{s}\end{cases}
$$

ここに， $z_{v}$ は流速一定に近似する水深である.

以上の考えに基づいて求めた近似表現流速分布の計算 值を, Fig. 11 に実測值と比較して示す. 同図の比較から, 上に述べた流速分布の近似法は実測流速分布を十分な精 度で表わし得るものと考えられる.

\section{7. 取水温度の推定法と検証}

\section{（1）軸対称模型水理実験結果との比較}

前に述べた温度勾配が変化する場合の選択取水数把握 実験の際に，取水温度の測定を同時に行った。その取水 温度と，流速分布実験式 (14)，および，式 (13) を用 いた計算取水温度とを比較し, 本研究で提示する取水温 度推定法の妥当性を検討する。
Fig. 9 に例示した種々の水温分布に対して, 取水温度 の推定計算を行うとともに，実測取水温度との比較を行 い両者間に現われる誤差を求めると, Fig. 12 に示す結 果が得られた。

この図に示すように，推定值の方が実測值に比し高く なる傾向がある．このような差が生じる要因としては, 二次元流について得られた流速分布の実験式 (4) を, 軸対称流に適用したこと，および取水設備の吞口近辺で 流動層と下層冷水域との間に混合が生じていること等が 考えられる.

\section{（2）実機計測結果との比較}

現地の貯水池において前掲の Fig. 7 の水温分布を測定 した際に，そこに設けられた選択取水設備での取水温度 も計測された（流動層厚さの計測も，小型のボートから 吊り下げたプロペラ流速計を用いて試みたが，十分な精 度が得られなかったのでここには示していない).

これらの実機条件，すなわち，実機における水温分布， 取水量および取水設備寸法を用いて，上に述べてきた手 法に沿って取水温度を推定し, 実測值と比較してみる. なおここに, 貯水池水温分布は, いずれのケースも, 取 水設備中心から $10 R(R$ は取水設備半径 $)$ の位置で計測 し, 取水温度は, 放水路において最も取水設備に近接し た位置で計測した。

計算に用いた諸数値を Table 2 に示すが，それらの算 定方法は以下のとおりである.

\section{i ）流動層厚さの推定}

流動層厚さの推定は, 選択取水数が Fig. 3 に示すよう に，取水設備寸法によって変化するために，密度勾配が 全水深にわたって一定の場合に対しても逐次近似計算と なる，具体的にはまず流動層厚さ $d_{s}$ を仮定した後, 密 度勾配および取水量 $Q$ を用いて, 選択取水数 $G_{c r}$ を求 める. 次に Fig. 6 においてその $G_{c r}$ は取水設備の半径 $R$ および吞口高さ $H$ の流動層厚さに対する比, すなわち $R / d_{s}$ および $H / d_{s}$ に対する $G_{c r}$ に整合しているか否か をチェックしていく.

密度勾配が変化する場合は， $G_{c r}$ のかわりに Fig. 10

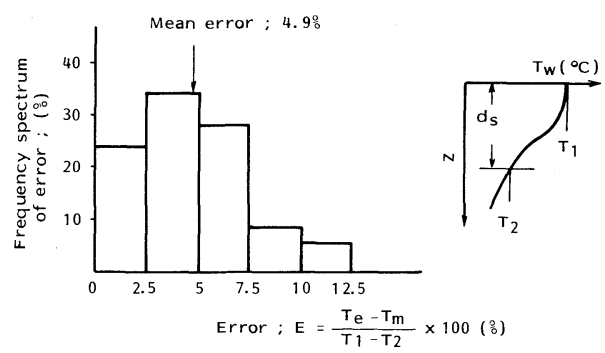

Fig. 14 Speactrum of Error of Estimated Withdrawal Water Temperatures to Measured Ones in Model Tests $\left(T_{e}\right.$ : Estimated temperature, $T_{m}$ : Measured temperature). 
Table 2 Calculation on Errors of Estimated Withdrawal Water Temperature to Measured ones for Prototype (Notations should be refered to Fig. 14).

\begin{tabular}{|c|c|c|c|c|}
\hline & & \multicolumn{3}{|c|}{ Name of Reservoir } \\
\hline & & Shokan & $\begin{array}{l}\text { Haboro- } \\
\text { futamata }\end{array}$ & Azuma \\
\hline \multicolumn{5}{|c|}{ Outline of intake structur } \\
\hline ( i ). Flow rate & $;(\mathrm{m} 3 / 5)$ & 6.5 & 2.8 & 4.5 \\
\hline (ii). Intake diamet & er; $(\mathrm{m})$ & 4.9 & 6.5 & 8 \\
\hline (iii). Cpening heig & $t ;(\mathrm{m})$ & 0.75 & 0.5 & 0.656 \\
\hline------ & & & & -- \\
\hline \multicolumn{5}{|l|}{ Calculation on errors } \\
\hline ( $\mathrm{i}) \cdot d s(e: p \in c t e d)$ & $;(\mathrm{m})$ & 3 & 2.2 & 2.2 \\
\hline (ii). Te(expected) & $;\left({ }^{\circ} \mathrm{C}\right)$ & 18.1 & 19.5 & 20.6 \\
\hline (iii). $\mathrm{Tm}^{\mathrm{m}}$ & $;\left({ }^{\circ} \mathrm{C}\right)$ & 17.2 & 18.8 & 20.6 \\
\hline$(\mathrm{iv}) \cdot \mathrm{T}_{1}$ & $;\left({ }^{\circ} \mathrm{C}\right)$ & 20.7 & 20 & 20.6 \\
\hline$(v) \cdot T_{2}$ & $;\left({ }^{\circ} \mathrm{C}\right)$ & 12.5 & 14.3 & 20.6 \\
\hline (vi). $T_{e}-T_{m}$ & $;\left({ }^{\circ} \mathrm{C}\right)$ & 0.9 & 0.7 & 0 \\
\hline$(V i i) \cdot E$ & $;\left(\begin{array}{ll}\circ & \circ\end{array}\right)$ & 11 & 12 & 0 \\
\hline
\end{tabular}

で補正される $G_{c r}^{\prime}$ を用いる.

\section{ii ）取水温度の推定}

流動層厚さが定まれば, 前述の模型水理実験結果に対 する検討と同手法により取水温度の推定が可能である.

以上のようにして求めた取水温度推定值と実測值とを Table 2 に示す. 同表にみることのできるように, 推定 計算取水温度は実測值に対して，0〜 $12 \%$ 高めの值を与 える. この誤差の原因のなかには, 実機においては放水 口で取水温度計測をするために, 取水口から放水口に至 る間の導水管に生ずる放熱の影響, またテレスコープ形 取水設備の継目や非常用取水ゲート部からの冷水侵入の 影響等も含まれていると考えられる.

\section{8. 結 び}

選択取水の研究に関しては, 日野・大西による point sink への流れの解明によって大きな進展を得たが, 実 機の設計を進めるには，まだいくつかの要検証事項およ び未解明点が残されていた。 ただし, 選択取水設備は火
力・原子力プラントの取水設備および貯水池の表層取水 あるいは中層取水等多様に適用されるので, 実機設計法 の確立を図る場合には, 各適用先に共通な原理的問題点 また，各適用先に固有の問題点の双方について明らかに していく必要がある.

これらの問題に対し，本研究ではまず原理的問題点と して, 取水口寸法が流動層厚さに及ぼす影響を明らかに し, 従来のポイントシンク理論を越えた実機の設計法に 関する新概念を示した.この研究においては, 日野・大 西の理論に基づき選択取水数 $G_{c r}$ の解析解を求めるとと もに，実験による検証を行った。

次に, 貯水池の表層取水を対象として, 密度勾配が非 直線的に変化する場合の選択取水数を実験的に把握し て, 直線的な密度勾配時の選択取水数との関係を示す Fig. 10 を提示した. さらに, 流動層内流速分布を LDV で計測して，それを取水温度算定に至便な実験式にまと めた。当論文に示した取水温度算定法は, 模型水理実験 結果および実機実測結果と照合すると0〜12\%高い值 を与えたが, それらの誤差を補正值として考え, 実用に 供することが可能であると考える。

\section{参 考 文 献}

1）日野幹雄・大西外明：密度成層流におよぼす point sink の高さの効果, 土木学会論文報告集, 第 163 号, pp. 39 $\sim 48,1963$.

2）大西外明・日野幹雄 : 深層取水の流れへの考察 II，第 15 回海岸工学講演会講演集, pp. 203 211, 1968.

3）日野幹雄 - 古沢 恵: 成層密度流体からの選択取水に関 する実験——層分離現象亡中層取水一, 第 16 回海岸工 学講演会講演集, pp. 231 236, 1969.

4）白砂孝夫 - 安芸周一：貯水池の濁水現象とその水理学的 軽減対策, 発電水力, No. 126, pp. 3 25, 1973.

5) Harleman, D.R.F : Temperature prediction in stratified reservoirs, Proc. ASCE, HY 4, pp. 645 666, Apr. 1972.

6）大西外明 - 今村建二 - 寺田 博 - 渋谷八郎：選択取水に おける取水口寸法の影響, 第 28 回海岸工学講演会論文集, pp. $490 \sim 494$.

7) Yih, C.S. : On the flow into a line sink, Procd. 3 rd U. S. Nat. Cong. of Appl. Mech., 1958.

(1985.5.27 - 受付) 